\title{
Cryptosporidium parvum upregulates miR-942-5p expression in HCT-8 cells via TLR2/ TLR4-NF-KB signaling
}

\author{
Guiling Zhang ${ }^{1}$, Yajun Zhang ${ }^{1}$, Ziwen Niu', Chenrong Wang ${ }^{1}$, Fujie Xie', Juanfeng Li', Sumei Zhang ${ }^{1}$, Meng Qi $^{2}$, \\ Fuchun Jian' ${ }^{1}$, Changshen Ning ${ }^{1}$, Longxian Zhang ${ }^{1 *}$ and Rongjun Wang ${ }^{1 *}$
}

\begin{abstract}
Background: Micro (mi)RNAs are small noncoding RNA molecules that function in RNA silencing and post-transcriptional regulation of gene expression. This study investigated host miRNA activity in the innate immune response to Cryptosporidium parvum infection.

Methods: In vitro infection model adopts HCT-8 human ileocecal adenocarcinoma cells infected with C. parvum. The expression of miR-942-5p was estimated using quantitative real-time polymerase chain reaction (qPCR). The TLRsNF-KB signaling was confirmed by qPCR, western blotting, TLR4- and TLR2-specific short-interfering (si)RNA, and NF-KB inhibition.

Results: HCT-8 cells express all known toll-like receptors (TLRs). Cryptosporidium parvum infection of cultured HCT-8 cells upregulated TLR2 and TLR4, and downstream TLR effectors, including NF-KB and suppressed IKBa (nuclear factor of kappa light polypeptide gene enhancer in B cells inhibitor, alpha). The expression of miR-942-5p was significantly upregulated at 4, 8, 12 and $24 \mathrm{~h}$ post-infection, and especially at $8 \mathrm{hpi}$. The results of TLR4- and TLR2-specific siRNA and NF-KB inhibition showed that upregulation of miR-942-5p was promoted by $p 65$ subunit-dependent TLR2/TLR4NF-KB pathway signaling.

Conclusions: miR-942-5p of HCT-8 cells was significantly upregulated after C. parvum infection, especially at 8 hpi, in response to a p65-dependent TLR2/TLR4-NF-KB signaling. TLR4 appeared to play a dominant role.
\end{abstract}

Keywords: Cryptosporidium parvum, HCT-8, TLRs, NF-KB, miR-942-5p

\section{Background}

Cryptosporidium is an emerging zoonotic pathogen that causes diarrhea in both immunocompetent and immunosuppressed hosts, and is second only to rotavirus as a cause of moderate-to-severe diarrhea in children under two years of age [1]. In immunocompromised patients, it can cause severe, life-threatening prolonged disease. In 2016, the disease burden of cryptosporidiosis in

*Correspondence: zhanglx8999@henau.edu.cn; wrj-1978@henau.edu.cn

${ }^{1}$ College of Veterinary Medicine, Henan Agricultural University, Zhengzhou 450046, P. R. China

Full list of author information is available at the end of the article children younger than five years was more than 12 million disability-adjusted life-years (DALYs) [2]. Thirtyeight Cryptosporidium valid species and approximate 60 Cryptosporidium genotypes have been identified or described in animals, humans, and environmental samples [3] but C. parvum and C. hominis are responsible for more than $90 \%$ of infections in humans. Despite recent efforts, effective prophylaxis and treatment are not available.

Micro (mi)RNAs are small noncoding RNA molecules found in plants, animals, viruses, and some parasite species. They function in RNA silencing and post-transcriptional regulation of gene expression [4]. Because C. parvum lacks

(c) The Author(s) 2020. This article is licensed under a Creative Commons Attribution 4.0 International License, which permits use, sharing, adaptation, distribution and reproduction in any medium or format, as long as you give appropriate credit to the original author(s) and the source, provide a link to the Creative Commons licence, and indicate if changes were made. The images or other third party material in this article are included in the article's Creative Commons licence, unless indicated otherwise in a credit line to the material. If material is not included in the article's Creative Commons licence and your intended use is not permitted by statutory regulation or exceeds the permitted use, you will need to obtain permission directly from the copyright holder. To view a copy of this licence, visit http://creativeco mmons.org/licenses/by/4.0/. The Creative Commons Public Domain Dedication waiver (http://creativecommons.org/publicdomain/ zero/1.0/) applies to the data made available in this article, unless otherwise stated in a credit line to the data. 
key components needed for small RNA-mediated posttranscriptional gene silencing, it is an ideal model for investigating miRNA-mediated defenses against infection in epithelial cells [5]. At least seven host miRNAs, let-7i, miR98, miR-513, miR-424, miR-503, miR-221 and miR-27b, are thought to be active in the innate immune defense against Cryptosporidium infection [6-13]. In biliary epithelial cells for example, C. parvum reduces the expression of let-7 family miRNAs, which target the synaptosome associated protein 23 (SNAP23) gene, and loss of SNAP23 expression interferes with the release of exosomes carrying antimicrobial-peptides [7].

As with other intracellular pathogens, Cryptosporidium infection influences apoptosis. Microarray analysis of 51 apoptosis-associated genes indicated biphasic regulation by Cryptosporidium, with an anti-apoptotic state at 6 and $12 \mathrm{~h}$ post-infection (hpi) and a moderately proapoptotic state at 24, 48 and $72 \mathrm{hpi}$ [14]. Inhibition of apoptosis in infected cells increases parasite survival and continuing apoptosis in uninfected bystander cells act to decrease the host immune response and may contribute to evasion of host defenses [15]. Previous studies have reported that Cryptosporidium inhibited of host-cell apoptosis by activating NF- $\mathrm{KB}[16,17]$. Little is known about the regulation of host-cell apoptosis by miRNAs following Cryptosporidium infection. A previous study found that downregulation of miR-513 was followed by the upregulation of $\mathrm{B} 7-\mathrm{H} 1$ expression and decreased apoptosis [11].

Our previous study of the miRNAs expressed in HCT-8 cells infected with $C$. parvum found that miR-942-5p, miR-181d, miR-3976, miR-18b-3p, miR-34b-5p and miR3591-3p may regulate apoptosis in the early phase of infection [18]. This study investigated the upregulation of miR-942-5p in cultured HCT-8 human ileocecal adenocarcinoma cells following activation of the TLR2/TLR4-NF- $\mathrm{kB}$ signaling pathway by C. parvum.

\section{Methods}

\section{Cryptosporidium oocysts and HCT-8 cells}

Cryptosporidium parvum subtype IIdA19G1 oocysts were maintained in infected neonatal calves and stored in $2.5 \% \mathrm{~K}_{2} \mathrm{Cr}_{2} \mathrm{O}_{7}$ solution at $4{ }^{\circ} \mathrm{C}$ after purification. As previously described, oocysts were excysted in $0.25 \%$ trypsin and $0.75 \%$ sodium taurocholate for $1 \mathrm{~h}$ with mixing every $5 \mathrm{~min}$, followed by incubation at room temperature for 30 min $[19,20]$. HCT-8 human ileocecal adenocarcinoma cells (American Type Culture Collection, Manassas, VA) were maintained in Dulbecco's modified Eagle's medium (DMEM) supplemented with $10 \%$ fetal bovine serum, 4 $\mathrm{mmol} / \mathrm{l} \mathrm{L}$-glutamine, $100 \mathrm{U} / \mathrm{ml}$ penicillin, and $100 \mathrm{U} / \mathrm{ml}$ streptomycin at $37{ }^{\circ} \mathrm{C}$ in a humidified $5 \% \mathrm{CO}_{2}$ incubator [18]. Cell monolayers in 24-well cell culture dishes were inoculated with $2.5 \times 10^{6}$ purified sporozoites per well in DMEM. The sporozoite:host-cell ratio was 10:1.

\section{Real-time quantitative PCR (qPCR)}

HCT-8 cells were washed three times with phosphate buffered saline (PBS) before adding $1 \mathrm{ml}$ TRIzol reagent (Invitrogen, Waltham, MA, USA) to each well. Total RNA was isolated following the kit manufacturer's instructions subsequent to treatment with Recombinant DNase I (Takara, Kyoto, Japan). RNA was reverse transcribed to cDNA with SuperScript IV Reverse Transcriptase (Invitrogen) by oligo (dT) and random primers. The cDNA was amplified using the TB Green Premix Ex Taq II (Takara, Kyoto, Japan) and the gene-specific primers shown in Table 1. GAPDH or $\beta$-actin genes were internal references for toll-like receptors (TLRs), the U6 gene was the internal reference for miR-942-5p. miR942-5p was reverse transcribed to cDNA using the stemloop primer (5'-GTC GTA TCC AGT GCA GGG TCC GAG GTA TTC GCA CTG GAT ACG ACC ACA TGG C-3') and the primer (5'-CGC TTC ACG AAT TTG CGT GTC AT-3') for U6. PCR included one 30 s cycle at $95^{\circ} \mathrm{C}, 40$ cycles of $5 \mathrm{~s}$ at $95^{\circ} \mathrm{C}, 10 \mathrm{~s}$ at $55^{\circ} \mathrm{C}$, and $15 \mathrm{~s}$ at $72^{\circ} \mathrm{C}$, and a final $15 \mathrm{~s}$ cycle at $95^{\circ} \mathrm{C}, 1 \mathrm{~min}$ at $60^{\circ} \mathrm{C}$, and infinite at $25^{\circ} \mathrm{C}$. The $\mathrm{Cq}$ values were analyzed using the comparative $\mathrm{Cq}(\Delta \Delta \mathrm{Cq})$ method and the amount of target was obtained by normalizing to internal reference and comparing with the control group.

\section{Western blotting}

HCT-8 cells were grown to $80 \%$ confluence in 6-well culture plates and exposed to C. parvum sporozoites. The cells were lysed with a total protein extraction kit (Solarbio Life Sciences, Beijing, China), and the protein concentrations were determined with a Pierce Bicinchoninic Acid (BCA) Assay Kit (Thermo Fisher Scientific, Waltham, MA, USA) following the manufacturer's instructions. The proteins in $30 \mu \mathrm{g}$ samples of lysate were separated by sodium dodecyl sulfate polyacrylamide gel electrophoresis (SDS-PAGE) and blotted onto nitrocellulose membranes. Membranes were incubated with TLR4, $\mathrm{NF}-\kappa \mathrm{B}, \mathrm{I} \kappa \mathrm{B} \alpha$, and $\beta$-actin primary monoclonal antibodies (Abcam, Cambridge, UK), and then with $0.2 \mu \mathrm{g} / \mathrm{ml}$ horseradish peroxidase (HRP)-conjugated secondary antibodies. The blots were read by an electrochemiluminescence (ECL) substrate (Thermo Fisher Scientific).

\section{Short-interfering (si)RNA}

SiRNAs targeting TLR-2 and TLR4 mRNAs were designed by the Sangon Biotech (Shanghai, China). HCT-8 cells were grown to $60-70 \%$ confluency in 12 -well cell culture plates and transfected with siRNAs using Lipofectamine 3000 (Thermo Fisher Scientific). The 
Table 1 Primer sequences used in $\mathrm{APCR}$

\begin{tabular}{lll}
\hline Target mRNA & Primers & \\
\cline { 2 - 3 } & Forward & Reverse \\
\hline TLR1 & GGTGTTGGCTGTGACTGTGA & TGGAGTTCTTCTAAGGGTATG \\
TLR2 & GATGCCTACTGGGTGAGA & AGACGGAATGGGAGAAGT \\
TLR3 & CCAAGCCTTCAACGACTG & TTGCGTGTTTCCAGAGCC \\
TLR4 & CCGCTTCCTGGTCTTATCAT & TCTGCTGCAACTCATTTCAT \\
TLR5 & CAACCTTACAGCGAACC & AAACATCCCAACAGAGC \\
TLR6 & CAGTTAATACTTTAGGGTGCT & CGTTTCTATGTGGTTGAGGG \\
TLR7 & CCTTTCCCAGAGCATACAGC & GGACAGAACTCCCACAGAGC \\
TLR8 & CAGAGCATCAACCAAAGCAA & GCTGCCGTAGCCTCAAATAC \\
TLR9 & GTGCAGCCGGAGATGTTT & CGTGAATGAGTGCTCGTGGTAG \\
TLR10 & GCCCACCACAATCTCTTCCA & GCCCACATTTACGCCTATCCTT \\
GAPDH & AGAAGGCTGGGGCTCATTTG & AGGGGCCATCCACAGTCTTC \\
U6 & GCTTCGGCAGCACATATACAAAAT & CGCTTCACGAATTGCGTGTCAT \\
-actin & AGCGAGCATCCCCCAAAGTT & GGGCACGAAGGCTCATCATT \\
\hline
\end{tabular}

extent of inhibition was determined by qPCR assays of TLR2 and TLR4 expression at $48 \mathrm{~h}$ post-transfection. The siRNAs that caused the greatest inhibition of TLR2, TLR4 expression were TLR2, GGA AGA UAA UGA ACA CCA ATT (sense) and UUG GUG UUC AUU AUC UUC CTT (antisense); TLR4, CCA GGU GCA UUU AAA GAA ATT (sense) and UUG GUG UUC AUU AUC UUC CTT (antisense). The siRNA oligonucleotides had no significant overlap with homologous gene sequences. Nonspecific siRNAs containing the same nucleotides in an irregular sequence were used as controls. The siRNAs were labeled with Cy3 using a silencer siRNA labeling kit (Thermo Fisher Scientific) for identification of transfected cells by confocal microscopy. HCT-8 cells were infected with $C$. parvum sporozoites $6 \mathrm{~h}$ after siRNA transfection. Total RNA was extracted at 0, 4, 8, 12, 24 and $48 \mathrm{hpi}$.

\section{Inhibitors}

Pyrrolidine dithiocarbamate (PDTC) and SC-514 (MedChemExpress, Monmouth Junction, NJ, USA) were used to inhibit NF- $\mathrm{kB}$ activation $[21,22]$. HCT-8 cells were pretreated with inhibitor for $2 \mathrm{~h}$ prior to C. parvum infection. PDTC and SC-514 were used at concentrations of $3.286 \mu \mathrm{g} / \mathrm{ml}$ and $22.43 \mu \mathrm{g} / \mathrm{ml}$, which were not cytotoxic in either HCT-8 cells or C. parvum sporozoites.

\section{Data analysis}

Data are represented as the mean \pm standard deviation (SD) from three independent experiments. Each independent experiment was conducted by three replicates of $\mathrm{qPCR}$ and the mean value was used for data analysis. One-way ANOVA or t-test was carried out using the software of GraphPad Prism version 8.02 (https://www.graphpad.com/).

\section{Results \\ Cryptosporidium parvum activation of TLR2 and TLR4 in HCT-8}

TLR1 to TLR10 expression was assayed by qPCR at 8 and 12 hpi. All were expressed in HCT-8 cells (Fig. 1a), but significant differences in infected and uninfected cells were observed only for TLR2 and TLR4. The difference was the greatest for TLR4 (TLR2 $4 \mathrm{~h}: t_{(4)}=4.961, P=$ 0.0077; TLR2 $12 \mathrm{~h}: t_{(4)}=4.052, P=0.0155$; TLR4 $4 \mathrm{~h}$ : $t_{(4)}=22.31, P=10^{-9}$; and TLR4 $12 \mathrm{~h}: t_{(4)}=12.18, P=$ 0.0003 by t-test: test versus non-infected cells) (Fig. 1b). Activation of the TLR/NF- $\mathrm{kB}$ signaling pathway was confirmed in western blots, which showed that expression of TLR 4 and NF- $\mathrm{B}$ increased and that of $\mathrm{I} \kappa \mathrm{B} \alpha$ decreased at both 8 and 12 hpi (Fig. 1c).

\section{Upregulation of miR-942-5p by Cryptosporidium parvum}

The qPCR results showed that miR-942-5p expression was significantly increased at 4, 8, 12 and $24 \mathrm{hpi}$, with the greatest difference compared with the control at $8 \mathrm{hpi}$ $\left(F_{(4,10)}=21.00,4 \mathrm{~h}: P=0.0121,8\right.$ h: $P=10^{-9}, 12 \mathrm{~h}: P=$ 0.0032 , and $24 \mathrm{~h}: P=0.0073$ by one-way ANOVA: test versus control group) (Fig. $2 \mathrm{a}$ ).

\section{Both TLR2 and TLR4 contribute to upregulation of miR-942-5p}

Our previous study found that miR-942-5p was strongly upregulated in HCT-8 cells following $C$. parvum infection, compared with uninfected cells [18]. In this study, 

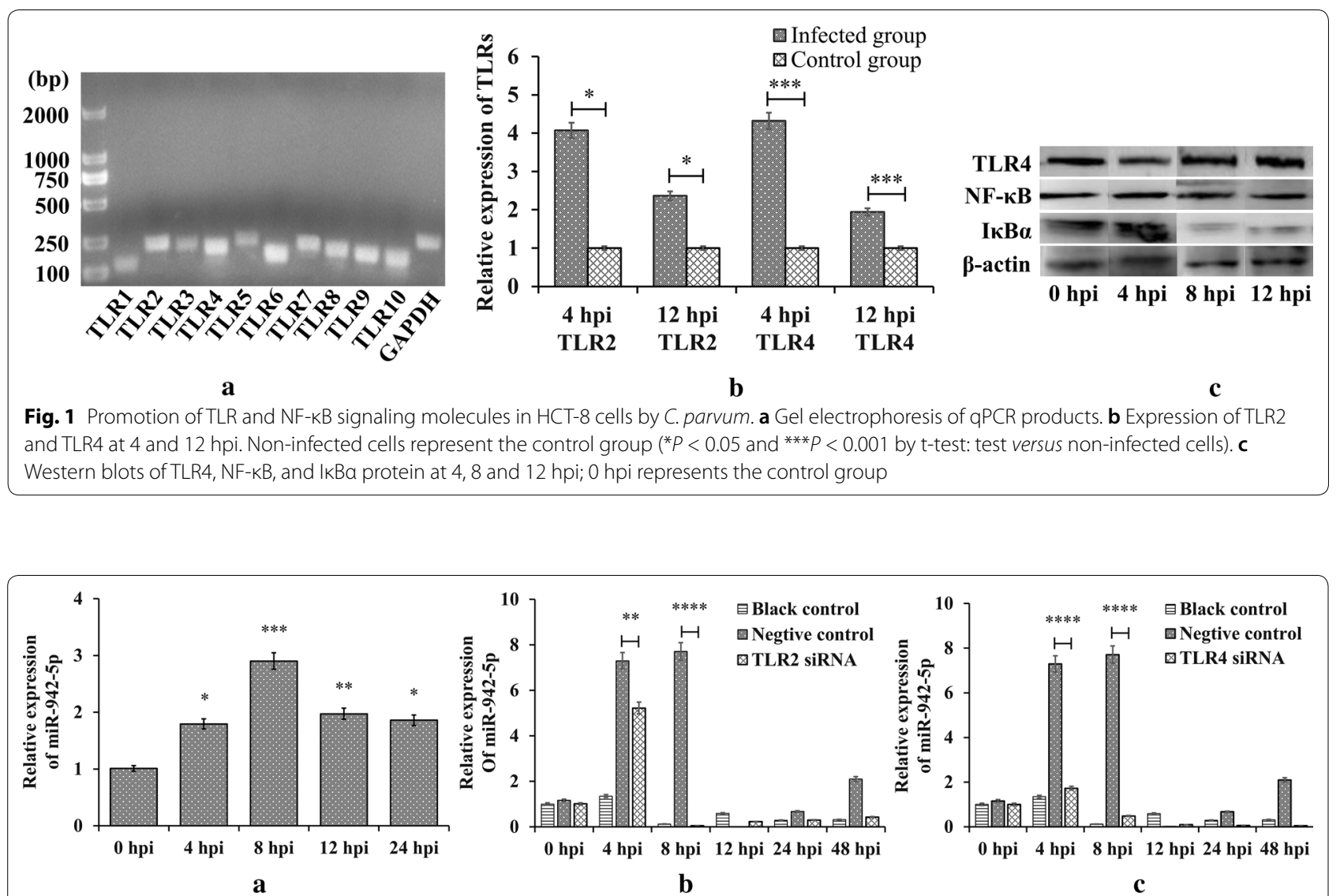

Fig. 2 miR-942-5p expression in HCT-8 cells. a miR-942-5p expression in HCT-8 cells infected by C. parvum (0 hpi represents the control group). $\mathbf{b}$ miR-942-5p expression in C. parvum-infected HCT-8 cells after transformation with TLR2-specific siRNA. c miR-942-5p expression in C. parvum-infected HCT-8 cells after transformation with TLR4-specific siRNA. Black control represents the group of non-infected cells ${ }^{*} P<0.05$, ${ }^{* *} P<$ $0.01,{ }^{* * *} P<0.001$ and ${ }^{* * *} P<0.0001$ by one-way ANOVA: test versus control group)

qPCR assays revealed that the transcription of the $m i R$ 942 gene was significantly decreased after blocking either TLR2 or TLR4 $\left(F_{(2,23)}=58.32, P=10^{-9}\right.$ by one-way ANOVA: test versus control group for Fig. $2 \mathrm{~b} ; F_{(2,27)}=$ 89.08, $P=10^{-9}$ for Fig. 2c) (Fig. 2b, c). TLR4 appeared to have a stronger influence on miR-942-5p transcription than TLR2.

\section{NF-KB p65 is required for the transcription of miR-942-5p} Inhibition of NF- $\kappa B$ by PDTC resulted in downregulation of miR-942-5p expression at 8 and 12 hpi compared with controls $\left(t_{(4)}=4.200, P=0.0137\right.$ by t-test: test versus inhibitor-negative group) (Fig. 3a). Inhibition of p65-associated transcriptional activation of the NF- $\mathrm{kB}$ pathway by SC-514, a nuclear factor kappa-B kinase-2 (IKK-2) inhibitor that prevents NF-kB-dependent gene expression, blocked the C. parvum-induced increase of miR-942-5p $\left(t_{(4)}=5.436, P=0.0056\right.$ by t-test: test versus inhibitor-negative group) (Fig. $3 \mathrm{~b}$ ). Promoter binding of the NF-kB p65 subunit was thus required for the transcription of miR-942 gene induced by C. parvum in HCT-8 cells.

\section{Discussion}

Cultured HCT-8 cells expressed all known TLRs (TLR1TLR10) and C. parvum infection induced the upregulation of TLR2 and TLR4, but not other TLRs, as was previously found in H69 human choanocyte cells [23]. Upregulation of TLR4 was stronger than that of TLR2 (Fig. 1b), but activation of either receptor recruited downstream components, with increased NF- $\kappa B$ expression and decreased expression of $\mathrm{I} \kappa \mathrm{B} \alpha$, an NF-kB inhibitor. Nuclear translocation of NF- $\kappa B$ activated transcription. TLR2- and TLR4-induced activation of NF- $\mathrm{kB}$ has previously been reported in $\mathrm{H} 69$ cells infected by $C$. parvum [23].

The upregulation of miR-942-5p after C. parvum infection was dependent on TLR2/TLR4-NF- $\mathrm{KB}$ signaling. TLR4 may have had a stronger effect than TLR2, especially at $4 \mathrm{hpi}$, but both TLR 2 and TLR4 contributed to 


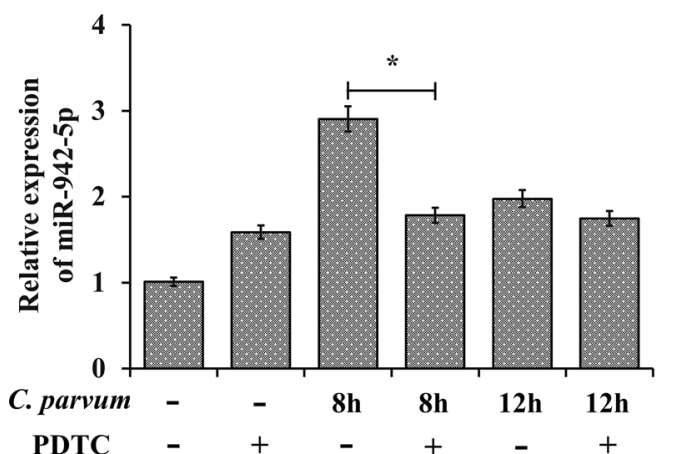

a

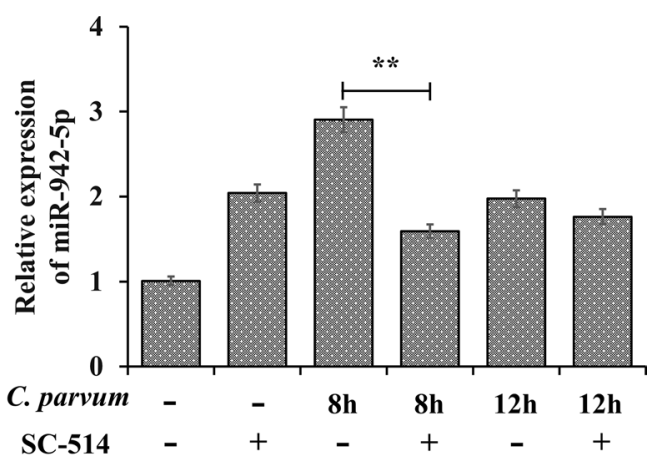

b

Fig. 3 miR-942-5p expression in C. parvum-infected HCT-8 cells pretreated with NF-kB inhibitors. a PDTC inhibition of NF-kB. b p65-dependent inhibition of NF-KB p65 by SC-514 $\left({ }^{*} P<0.05\right.$ and ${ }^{* *} P<0.01$ by t-test: test versus inhibitor-negative group)

the upregulation of miR-942-5p expression (Fig. 2b, c). There are few data on the difference in the contributions of TLR2 and TLR4 during C. parvum infection, but TLR4-NF-KB signaling has been reported more frequently. TLR2 may be involved in C. parvum-induced stabilization of iNOS mRNA expression in biliary epithelial cells [13]. Post-transcriptional suppression of TLR4 expression by let- $7 i$ has been shown to contribute to immune responses to C. parvum infection in cultured human cholangiocytes, and mu-miR-92a-2-5p, which targets TLR2, relieves Schistosoma japonicum-induced liver fibrosis [6, 24].

A microarray analysis found that miR-942-5p was strongly upregulated during the early phase of C. parvum infection, and in this study qPCR confirmed that C. parvum infection was followed by significant upregulation of miR-942-5p at 4, 8, 12 and 24 hpi (Fig. 2a). Bioinformatics analysis indicated that miR-942-5p may be involved in the regulation of host-cell apoptosis. Previous studies have shown that miR-942 regulated cell apoptosis in response to microbial infection. For example, downregulation of miR-942 enhanced the apoptosis of HLCZ01 cells in response to hepatitis $C$ virus infection [25]. Targeting of the IFI27 gene by miR-942-5p has been shown to inhibit apoptosis role in HCT-8 cells during the early phase of C. parvum infection (our unpublished data).

\section{Conclusions}

HCT-8 cells expressed all known TLRs, and TLR2 and TLR4 were upregulated following C. parvum infection with activation of downstream signaling. miR-942-5p was significantly upregulated after C. parvum infection, especially at $8 \mathrm{hpi}$, in response to a p65-dependent TLR2/ TLR4-NF-kB signaling. TLR4 appeared to play a dominant role.

\section{Abbreviations}

HCT-8 cells: HCT-8 human ileocecal adenocarcinoma cells; qPCR: real-time quantitative polymerase chain reaction; siRNA: short-interfering RNA; NF-KB: nuclear factor kappa-light-chain-enhancer of activated B cells; IKBa: nuclear factor of kappa light polypeptide gene enhancer in B cells inhibitor, alpha; PBS: phosphate buffered saline; TLRs: toll like receptors; SDS-PAGE: sodium dodecyl sulfate polyacrylamide gel electrophoresis; PDTC: pyrrolidine dithiocarbamate.

\section{Acknowledgements}

We thank International Science Editing-China (http://www.internationalsc ienceediting.cn/), for editing the English text of a draft of this manuscript.

\section{Authors' contributions}

$R W$ and $L Z$ conceived and designed the experiments; $G Z, Y Z, Z N, C W, F X$ and JL performed the experiments; GZ, SZ, MQ, FJ and CN analyzed the data; RW, GZ and $Y Z$ wrote the paper. All authors read and approved the final manuscript.

\section{Funding}

This research was funded by the National Key Research and Development Program of China (Grant Numbers 2017YFD0500405, 2017YFD0501305), the National Natural Science Foundation of China (Grant Number 31672548), and the Natural Science Foundation of Henan Province (Grant Number 162300410129).

\section{Availability of data and materials}

Data are available from the authors upon reasonable request.

\section{Ethics approval and consent to participate}

The present study was approved by the Independent Ethics Committee of Henan Agricultural University (Approval No. IEC-HENAU-20180323-06).

\section{Consent for publication}

Not applicable.

\section{Competing interests}

The authors declare that they have no competing interests.

\section{Author details}

${ }^{1}$ College of Veterinary Medicine, Henan Agricultural University, Zhengzhou 450046, P. R. China. ${ }^{2}$ College of Animal Science, Tarim University, Alar 843300, Xinjiang, P. R. China.

Received: 16 April 2020 Accepted: 24 August 2020

Published online: 31 August 2020 


\section{References}

1. Kotlo KL, Nataro JP, Blackwelder WC, Nasrin D, Farag TH, Panchalingam $\mathrm{S}$, et al. Burden and aetiology of diarrhoeal disease in infants and young children in developing countries (the Global Enteric Multicenter Study, GEMS): a prospective, case-control study. Lancet. 2013:382:209-22.

2. Khalil IA, Troeger C, Rao PC, Blacker BF, Brown A, Brewer TG, et al. Morbidity, mortality, and long-term consequences associated with diarrhoea from Cryptosporidium infection in children younger than 5 years: a metaanalyses study. Lancet Glob Health. 2018:6:e758-68.

3. Xie F, Zhang Z, Zhao A, Jing B, Qi M, Wang R. Molecular characterization of Cryptosporidium and Enterocytozoon bieneusi in Père David's deer (Elaphurus davidianus) from Shishou, China. Int J Parasitol Parasites Wildl. 2019;10:184-7.

4. Bartel DP. Metazoan MicroRNAs. Cell. 2018;173:20-51.

5. Abrahamsen MS, Templeton TJ, Enomoto S, Abrahante JE, Zhu G, Lancto CA, et al. Complete genome sequence of the Apicomplexan, Cryptosporidium parvum. Science. 2004;304:441-5.

6. Chen XM, Splinter PL, O'Hara SP, LaRusso NF. A cellular micro-RNA, let-7i, regulates Toll-like receptor 4 expression and contributes to cholangiocyte immune responses against Cryptosporidium parvum infection. J Bio Chem. 2007;282:28929-38.

7. Hu G, Gong AY, Roth AL, Huang BQ, Ward HD, Zhu G, et al. Release of luminal exosomes contributes to TLR4-mediated epithelial antimicrobia defense. PLoS Pathog. 2013;9:e1003261.

8. Hu G, Zhou R, Liu J, Gong AY, Chen XM. MicroRNA-98 and let-7 regulate expression of suppressor of cytokine signaling 4 in biliary epithelial cells in response to Cryptosporidium parvum infection. J Infect Dis. 2010;202:125-35.

9. Hu G, Zhou R, Liu J, Gong AY, Eischeid AN, Dittman JW, Chen XM. MicroRNA-98 and let-7 confer cholangiocyte expression of cytokine-inducible Src homology 2-containing protein in response to microbial challenge. J Immunol. 2009;183:1617-24.

10. Gong AY, Hu G, Zhou R, Liu J, Feng Y, Soukup GA, Chen XM. MicroRNA-221 controls expression of intercellular adhesion molecule-1 in epithelial cells in response to Cryptosporidium parvum infection. Int J Parasitol. 2011:41:397-403.

11. Gong AY, Zhou R, Hu G, Liu J, Sosnowska D, Drescher KM, Dong H, Chen XM. Cryptosporidium parvum induces $\mathrm{B} 7-\mathrm{H} 1$ expression in cholangiocytes by down-regulating microRNA-513. J Infect Dis. 2010;201:160-9.

12. Zhou R, Gong AY, Chen D, Miller RE, Eischeid AN, Chen XM. Histone deacetylases and NF-KB signaling coordinate expression of CX3CL1 in epithelial cells in response to microbial challenge by suppressing miR424 and miR-503. PLOS ONE. 2013;8:e65153.

13. Zhou R, Gong AY, Eischeid AN, Chen XM. miR-27b targets KSRP to coordinate TLR4-mediated epithelial defense against Cryptosporidium parvum infection. PLoS Pathog. 2012;8:el002702.
14. Liu J, Deng M, Lancto CA, Abrahamsen MS, Rutherford MS, Enomoto S. Biphasic modulation of apoptotic pathways in Cryptosporidium parvum infected human intestinal epithelial cells. Infect Immun. 2009;77:837-49.

15. Hu G, Feng Y, O'Hara SP, Chen XM. Immunology of cryptosporidiosis. In: Caccio SM, Widmer G, editors. Cryptosporidium: parasite and disease. Wien: Springer-Verlag; 2014. p. 423-54

16. McCole DF, Eckmann L, Laurent F, Kagnoff MF. Intestinal epithelial cell apoptosis following Cryptosporidium parvum infection. Infect Immun. 2000;68:1710-3.

17. Chen XM, Levine SA, Splinter PL, Tietz PS, Ganong AL, Jobin C, Gores GJ, Paya CV, LaRusso NF. Cryptosporidium parvum activates nuclear factor kappaB in biliary epithelia preventing epithelial cell apoptosis. Gastroenterology. 2001;120:1774-83.

18. Wang C, Liu L, Zhu H, Zhang L, Wang R, Zhang Z, et al. MicroRNA expression profile of HCT-8 cells in the early phase of Cryptosporidium parvum infection. BMC Genomics. 2019;20:37.

19. Huang L, Zhu H, Zhang S, Wang R, Liu L, Jian F, Ning C, Zhang L. An in vitro model of infection of chicken embryos by Cryptosporidium baileyi. Exp Parasitol. 2014;147:41-7.

20. Zhang S, Jian F, Zhao G, Huang L, Zhang L, Ning C, Wang R, Qi M, Xiao L. Chick embryo tracheal organ: a new and effective in vitro culture model for Cryptosporidium baileyi. Vet Parasitol. 2012;188:376-81.

21. Zhou R, Hu G, Gong AY, Chen XM. Binding of NF-kappaB p65 subunit to the promoter elements is involved in LPS-induced transactivation of miRNA genes in human biliary epithelial cells. Nucleic Acids Res. 2010;38:3222-32

22. Chen $H$, Lin $W$, Lin $P$, Zheng $M$, Lai Y, Chen $M$, et al. IL-10 produces a dual effect on OGD-induced neuronal apoptosis of cultured cortical neurons via the NF-kB pathway. Aging (Albany NY). 2019;11:10796-813.

23. Chen XM, O'Hara SP, Nelson JB, Splinter PL, Small AJ, Tietz PS, Limper AH, LaRusso NF. Multiple TLRs are expressed in human cholangiocytes and mediate host epithelial defense responses to Cryptosporidium parvum via activation of NF-kappaB. J Immunol. 2005;175:7447-56.

24. Zhao Y, Dang Z, Chong S. Mmu-miR-92a-2-5p targets TLR2 to relieve Schistosoma japonicum-induced liver fibrosis. Int Immunopharmacol. 2019:69:126-35.

25. Yang D, Meng X, Xue B, Liu N, Wang X, Zhu H. MiR-942 mediates hepatitis $C$ virus-induced apoptosis via regulation of ISG12a. PLoS One. 2014;9:e94501.

\section{Publisher's Note}

Springer Nature remains neutral with regard to jurisdictional claims in published maps and institutional affiliations.
Ready to submit your research? Choose BMC and benefit from:

- fast, convenient online submission

- thorough peer review by experienced researchers in your field

- rapid publication on acceptance

- support for research data, including large and complex data types

- gold Open Access which fosters wider collaboration and increased citations

- maximum visibility for your research: over 100M website views per year

At BMC, research is always in progress.

Learn more biomedcentral.com/submissions 